\title{
The Implementation of Prophetic Education at Junior High School Level
}

\author{
Arif Ahmad Fauzi \\ Adinda Kamilah
}

\begin{abstract}
The current educational process is moving from a monotonous, indoctrinate, teacher-centered, top-down, mechanical, verbal, and cognitive process. However, there is an impression that the current practice of Islamic education is sterile from the context of the reality that it is unable to contribute to the various problems that occur. One of the educational problems in adolescents is reflected in the data from the social services. There are five of the eight cases handled by the social service for the protection of women and children are juvenile delinquency cases. Therefore, we need an interpretation and reorientation as well as a paradigm shift from current educational practices. As Muslims, we have the Messenger of Allah as a role model for education. The teaching prophetic techniques and methods can change generations and create a masterpiece in the form of khairu ummah. Among the principles of prophetic education is to strengthen faith before studying the Qur'an. Prophetic education also has a basis on which to become the foundation. The implementation of prophetic education itself consists of several processes, namely planning, organizing, implementing, and evaluating. This study aims to examine the entire process of implementing prophetic education at the secondary school level, especially in SMP Bina Insan Boarding School. The research method used is field research and library research. The data are then analyzed theoretically and philosophically for further conclusions.
\end{abstract}

Keywords: Islamic education, implementation, prophetic

\section{Pendahuluan}

Educational methods for children or students today are so many and varied. Each school offers excellent methods to attract the hearts of parents to entrust their children to the educational institutions they manage. A simple scheme in the course of an institution is, of course, inseparable from the quality and role of the inputs, processes and outputs produced. Every parent certainly has hopes for the future of their children. The output is the final result of an educational institution after a long process of teaching and learning. The success of an educational institution can be measured by the target or final achievement of students. After graduating students, it can be seen what 
percentage of children can meet the target achievement or vision and mission of the educational institution taken. From that, it can also be seen whether the educational methods applied have been successful or not.

Rasulullah Muhammad's education is a noble education that produces noble people, his curriculum is not as complex as today's curriculum. The teacher is only Rasulullah SAW, but the students are multi-age and crossgenerational. Rasulullah was able to make changes in the community of ignorance through his dakwah and education.

Changes that occur in society are sunatullah and a necessity that cannot be prevented or stopped. Islam has guidelines that in fact, Allah SWT will not change the fate of a people until that people change their fate according to their abilities. Allah SWT said:

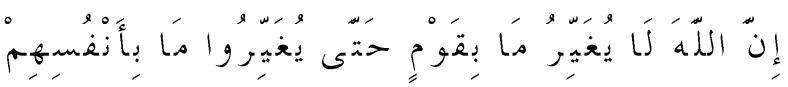

"Surely Allah will not change the fate of a people so that they change the situation that is in themselves."

As a Muslim, we should believe that the Prophet was the best teacher of all time, especially in terms of change. How he changes the ignorant community into a civilized, virtuous, and noble society. The companions are the students of the Prophet. History witnesses that they are the best generation that has ever been presented to humans on this earth. Rasulullah was sent to improve the earth and its inhabitants. He is present in the midst of generations who have neglected and forgot about His creator. They live in the flow of ignorance, lust is their God, the law that is enforced is the law of the jungle, the strong and powerful oppress the weak. The situation in the era of ignorance did not benefit education, but the Prophet succeeded in changing it. Through the Prophet Muhammad was born a just leader of the earth, a prosperous society, a civilized generation and became the best people. This is as the following hadith of the Prophet:

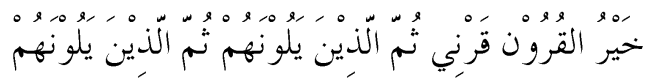

"The best of times is the age of mine (the Sahaba) then after, then after"

Starting from the historical evidence, we believe that the Prophet was the greatest teacher, his education was noble, and his methods were extraordinary. Thus, Rasulullah deserves to be a role model in the world of education.

Rasulullah taught a curriculum of faith to the people of Mecca, especially their friends. Several figures of little friends got the Prophet Muhammad's direct touch. History has clearly recorded the achievements of the Prophet Muhammad that the children who were trained by the Prophet would become the ones who carved out the greatness of Islam. Abdullah bin Zubair, Abdullah bin Abbas, Abdullah bin Amr bin Ash, Abdullah bin Umar, Anas bin Malik, Abdullah bin Ja'far, Usamah bin Zaid Radhiallahu 'anhum and other names. They are a small part of the children who touch and are educated directly by the Prophet Muhammad in their daily lives. Friends are provided with prophetic 
education before the Qur'an and adab before knowledge, this is as conveyed by the friend Jundub Bin Abdillah:

"We were always with the prophet when we were teenagers, we learned the faith first before learning the Qur'an. Then when we studied the Qur'an, our faith increased." (Sunan Ibn Majah)

The role of Islamic education is demanded to re-purify the direction of the nation's journey. The world of Islamic education is currently being challenged because of the demands of modernity as well as a role demand to always maintain moral and ethical values. In an era that is full of challenges of modernity, Islamic education is required to be able to produce individual seeds who are able to compete and master science but also have a great character that can be accounted for.

Today there are many educational terms known as character building. Some educators take concepts from today's world qibla, others modify existing ones, and some try to research themselves. Some Islamic schools try to formulate character education by involving all teachers to record all children's problems throughout the year, to then formulate a solution. Each educational institution competes to present the concept of character education. Some even proclaim the concept as an Islamic character. Even though this Islamic character must have a clear concept, foundation and illustration of a clear nubuwah application.

Education is an important component in human survival. Through education, the potential and talents of students can be developed, so that students are expected to become individuals who are beneficial to themselves and to many people. According to Makki, a nation can be said to be advanced if education in that nation is also advanced. On the other hand, a nation will be declared a backward nation if the education in that nation does not develop. (Asmani, 2013)

In the world of education which is full of challenges of modernization and globalization today, humans as agents of change are required to be able to play their roles proactively and dynamically (Shofan, 2004). Through education, students are expected to be able to make meaningful contributions to the improvement of generations, both intellectually, morally, spiritually, and to be able to find solutions to problems in the life of the nation and society.

The attention of the world of education is not only focused on matters of an academic but also non-academics. Character, moral, ethical, and mental education is being intensively prepared to build the civilization of a nation. Some educational institutions do not pay attention to the spiritual side of the essence of education. The high science of low morals, the great inventions of bad morals, the sophisticated technology of corrupt morals, immoral leaders, immoral educators, immoral people, living a household life without a process of moral improvement. A long journey of life that ends with anxiety and misery. 
Education in Indonesia has been going on for decades but has not fully demonstrated the quality and success expected. Because it only emphasizes the cognitive dimension that wants to produce smart, skilled, and adept humans, but it does not emphasize the affective dimension so that there are many lies, corruption, nepotism, and a series of other evils. This individual is illustrated as a figure of a nation who is in a split personality condition, which means a split or incomplete personality. Some of the crises experienced by the Indonesian people stem from moral, ethical, and moral crises, which are directly or indirectly related to the educational process, causing damage to individual societies collectively which later becomes culture. This culture has long been inherent in Indonesian society, so that it is considered the character of the nation. (Fitri Zainul, 2014)

According to Gusdur (in Fitri, 2014), the Indonesian nation has failed in the education process in five ways, they are: (1) failing to teach history, so that people do not appreciate the services and struggles of heroes; (2) failing to teach language resulting in sarcasm (violence and language distortion) in Indonesia; (3) failing to teach the philosophy that results in people and leaders being unwise in making decisions; (4) failing to teach mathematics so that society and future generations are more inclined towards mystical and superstitious; (5) failing to teach morals (morals) so that there are many crimes, anarchism, and terrorism in Indonesia.

In order to eradicate ignorance, the government always endeavors to support and develop various programs and methods for the sake of education. Various facilities, assistance, and efforts to make people aware of the importance of education continue to be encouraged by the government. Many schools and educational institutions have been established to help realize the government's aspirations in advancing the education of this nation. However, the facts on the ground show that many goals and outputs from educational institutions only produce workers, so that the orientation of education today is more likely to get a sheet of paper as a condition for being able to work. This has become inconsistent in building a noble national civilization.

The number of schools from SD (Primary School) to senior high school (SLTA), including Special Schools (SLB) in Indonesia, reached 307,655 schools as of 2017/2018. Based on basic education data from the Ministry of Education and Culture, this number consists of 169,378 public schools and 138,277 private schools. In 2020, of course, there will be more schools available as learning facilities. Referring to the National Education System Law Number $20 / 2003$, the results of education must be able to create people who are faithful and cautious, have noble character, knowledge, and skills, are physically and mentally healthy, have a stable and independent personality, and have responsibility for society and the nation. The reality today shows that the changing times marked by advances in science and technology always result in social change, with the increasingly sophisticated communication technology, 
transportation, and information systems making changes in society also faster to create a modern society. In such a situation, adolescents often have a more sensitive soul, which in the end many teenagers fall into things that are contrary to moral values, religious norms, social norms, and norms of life in society. Therefore adolescents will tend to have unnatural behavior in the sense of committing inappropriate actions which we are more familiar with juvenile delinquency.

Based on central data from the Social Affairs Office of Women's Empowerment and Child Protection, as of May 2020, out of a total of 8 cases handled, 5 of them were juvenile delinquency. As for cases of delinquency of children or adolescents that occur from the consumption of alcoholic beverages, theft, brawls, and immoral acts.

This generation must be improved, one of the alternatives to overcome this problem is through the internalization of prophetic and civilized education to restore the declining national identity to a nation with noble character, virtuous character and superior civilization. And a figure that should be used as an example is the Prophet Muhammad SAW. He is the prototype of the human being as an extraordinary teacher. He succeeded in leading the ummah with high morals, who always adhered to the scriptures and always gave examples or uswah hasanah that should be used as role models for their ummah, so that the prophetic education model became an alternative for the advancement of this nation's education.

Building a generation is like building a magnificent and large building. The Prophet Muhammad SAW made an analogy about the relationship between individuals as a result of Islamic education as a neatly arranged building that strengthens all joints. This is written in the hadith "A Mu'min with another Mu'min is like a building that strengthens one each other." (Narrated by Bukhari and Muslim).

The Prophet Muhammad SAW explained about quality in a language that is more appropriate and hits, "Man is a silver and gold mine. The one who is chosen (best) during jahiliyyah will be the chosen one (best) during Islam as long as he is faqih (has a deep understanding of knowledge). The spirits are junud-mujannadah. Those who know each other will be close and united while those who are opposite will be different (separate). " (HR. Muslim).

Imam Nawawi explained in Al Minhaj about the meaning of the sentence junud -mujannadah, "The scholars (Ulama) say that the meaning is a united association or different kinds. As for what is meant by knowing each other is something that Allah made to be united to him. It is also said to be the same in the nature that Allah Ta'ala has given and according to a character. So good people will tend to good people and bad people will tend to bad people. Allah knows best. There are several things we can understand from this hadith, namely: 
1. This generation was created by Allah Subhanahu wa Ta'ala differently, so it must be understood by parents, teachers, and educators of this generation that there must be differences.

2. There is gold, there is silver. This division simplifies the sharing of generational qualities. Gold and silver are distinctly different. At first glance gold is better than silver, especially at their price. But if silver played a role in its territory, which could not be replaced by anything even gold, then surely silver was more valuable in that place than gold. It implies that there are two key principles related to education: 1) Do not get the wrong generation in its role in this life; 2) Whether gold or silver, the most important thing is to be the highest quality, shiny, and most expensive in its class. Generational quality, whether gold or silver, will sparkle if it is in a place that matches its kind and has a deep understanding of knowledge.

Rasulullah SAW compared things related to quality in the words "In fact, humans are like a hundred camels, it is almost very difficult to find him spiritually (rohilah)." (Narrated by Bukhari and Muslim). Ibn Hajar explains in Fath al-Bari that the meaning is: "it's difficult to find on 100 camels there is spiritual one that is worthy to ride. Because what is worth driving is one that is tame and easy to control. Likewise, it is difficult for you to find 100 people who are worthy to be good friends who help their friends and are gentle in spirit. "

Ibn Hajar also quoted Al Khattabi's explanation that most humans are owners of deficiency. As for the main (noble) people, they are very few in number. They are like spirituality to load-bearing camels. As for An Nawawi, explaining this hadith from al Minhaj, he said, "Rohilah is a person who is pleased, perfect in character, good to look at, strong to carry burdens and journey."

The conclusions based on the hadith are: 1) The Prophet gave the number one hundredth for a quality generation; 2) A qualified generation is a spiritual generation, who is worthy of the burden and long journey of this civilization; 3) Small numbers are not a problem. As Mecca started with 5 people, Medina started with 6 people, Yemen started with a Mu'adz, and Madinah needed a Mush'ab. So, if in this country the number of Muslims is two hundred million, then there must be at least two million spiritual generations.

Based on the hadiths above, there are 3 keywords for the quality of the generation: 1) A generation that is fit to build; 2) Generations that sparkle like silver or gold; 3) A decent generation to carry the burden and take the long journey of civilization.

Regarding the concept of prophet education, it can be concluded that the generation of conceptions must have a religious personality who produces a faith-based concept with the main reference in the Al-Qur'an. Meanwhile, the executor generation must have a religious personality who becomes an actor in the field of civilization with faith-based skills and creativity regarding the AlQur'an. The generation of leaders who combine the two must have a religious 
personality who regulates the quality and work of faith-based civilization with the main reference of the Al-Qur'an.

\section{THEORETICAL STUDY}

\section{Concept of Islamic Education}

Education in Arabic is often referred to tarbiyah (التربية) which is taken

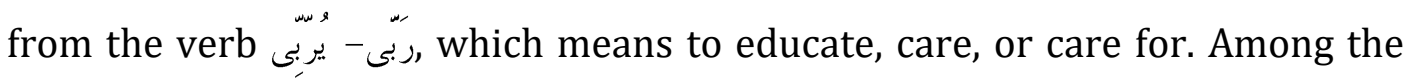
goals of Islamic education is to form a Muslim person who is whole and has great character and virtue. Islamic education is expected to be able to create human beings who are both physically and spiritually and make people aware of the essence of Allah as Khaliq (creator) and the essence of himself as a creature (created).

The purpose of creating humans is as abid and khalifa whose task is to worship and become khalifa to prosper the earth. Islam requires every Muslim to become an educated human through a learning process. So, it can be concluded that the purpose of Islamic education is as a form of preparation to create happiness in the world and the hereafter both physically and spiritually. Prophetic Concepts

Prophetic comes from the word prophetic which means anything related to the Prophet. Prophetic in Arabic means النبوية which means everything that comes from the Prophet Muhammad in the form of words, deeds, and provisions. Prophetic in this case refers to two missions, namely: 1) conveying revelations from Allah to the people who are often referred to as Rasulullah (Messenger);2) receive revelation but are not ordered to convey it to the people who are known as Prophet. (Roqib \& Abdul Wachid, 2011)

The Qur'an explains that the Prophet was an ideal servant of Allah SWT physically (in good health with optimal function) and psychologically (with a clean and intelligent spirit) who was close to Allah and His angels. The Prophet was given revelation and holy books as well as wisdom. Because of that, he was able to implement every teaching from Allah in his life, was able to communicate and convey effectively to humans. The prophetic potential exists in individuals who carry out an educational process based on prophetic values in the Al-Qur'an, as-sunnah, and ijtihad after going through various attempts at thinking (tafakkur) which result in finding normative and factual truths. This philosophical thought is then called prophetic philosophy.

With the potential that Allah gave, the Prophet was able to convey messages and build people to become the best people who were physically and mentally prosperous. Every Prophet has noble qualities, they are: (1) As-Siddiq: honest, (2) Amanah: trustworthy, (3) Tablig: communicative which means always preaching or conveying teachings and truth, and (4) Fatanah: intelligent. Ulama who are the inheritors of the prophets is required to be able to understand and carry out the main mission of a prophet. This prophetic mission 
is following the development of the scriptures, such: (1) explaining His teachings, (2) preaching and conveying God's teachings following His commands, (3) deciding cases or problems that are often faced by society, (4) ) provide examples of practice / exemplary to the people. If we interpret these four tasks and missions from an educational perspective, then the prophet's first task is to understand the word of God, which means that the prophet must master divine knowledge that will become material that can be explained to the people or students. Second, convey the material to the people (students). Third, carry out control and evaluation to prevent misuse by the people or students by disciplining themselves so that educational goals can be applied in life. Fourth, a prophet as God's representative on earth who has the nature of being an ordinary human being must be an ideal role model personally and socially. (AlIk, 2017)

The prophetic paradigm has four bases, namely: faith, Al-Qur'an, prophets, and knowledge. The meaning of each basis is as follows.

1. Faith

Humans have the will and the potential to have faith in Allah. The religious instinct is one of the potentials that God has given to humans. This is called the fitrah of tauhid. If there is a human being who denies the existence of Allah and does not believe in Him, it means that he has denied his essence (fitrah) and instincts.

The fitrah of faith (tauhid) is the basis of the Prophet's method of educating and producing extraordinary companions. Jundub bin Abdullah one of the Prophet's companions said:

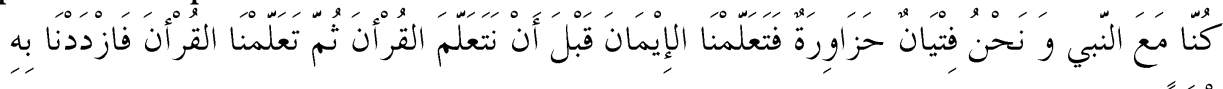

إيمانَا

"We were always with the Prophet when we were teenagers, we learned the faith first before learning the Al-Quran. Then when we learned the Qur'an, our faith grew. " (Sunan Ibn Majah)

Thabrani and Al Baihaqi in the book Syu'bul Iman explain that there are additional sentences from Jundub:

$$
\text { فإنّكم اليو تتعلمون القرأن قبل الإيمان }
$$

"As for you, today you studied the Qur'an before faith."

If we want to repeat the greatness of Islam then the learning stages of those two things we must start doing as much and as possible in our lives. The combination of faith and the Al-Qur'an will produce a strong personality with a noble character with the light of knowledge based on the Qur'an to reach a generation with Islamic civilization because prophetic education is the real Islamic character building. So what is meant by faithful (Imani) character? The meaning of faith character and how to teach and instill it is as conveyed in the following hadith:

Abu Hurairah said the words of the Prophet Muhammad: 


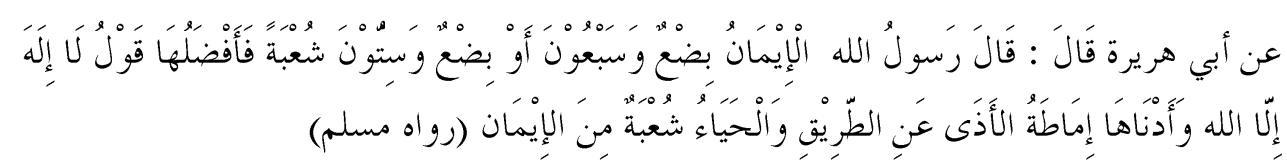

Abu Hurairah says that Rasulullah SAW said: "Faith has about 70's or 60 's of branches. The highest (main) of them is the sentence (speech) Laa Ilaaha Illaa Allah (there is no God but Allah) and the lowest of them is to remove something painful (dangerous) from the path. And shame is one of the branches of faith". (HR. Muslim).

Faith (Tawhid) includes all life. Faith becomes the spirit of every activity. Faith must also be the result of every human movement and activity. Ibn Hajar explained about the division of Ibn Hibban in matters of branches of faith. Ibn Hibban managed to collect branches of faith from various sources, there are 69 branches of faith according to Ibnu Hibban.

The following is Ibn Hajar's explanation:

1) 24 branches represent faith in the form of heart charity (35\%).

2) 7 branches represent faith in the form of oral charity (10\%).

3) 38 branches represent faith in the form of physical charity (55\%).

He concluded about this composition that:

1) The heart is first and foremost because the guarantee is that if the heart is good, then everything (verbal and physical) will be good. On the other hand, if the heart is damaged, it will also be damaged verbally and physically. So, $35 \%$ of this part covers the other $65 \%$.

2) Oral only $10 \%$, but determines whether a person remains istiqomah in kindness or not. Oral is the result of the heart and word will determine human behavior. Whether he will be consistent in goodness or not, will he avoid bad (words) or not.

3) Physical is the result of the heart being guarded by word of mouth. The physical percentage is greatest but the position lasts because it is the result.

Regardless of the branch of faith, faith has the main pillar. The main pillar is what we know as arkanul iman (pillars of faith). Rukun in Arabic means the main pillar. So if it is called the main pillar of faith, this indicates that the six pillars of faith are the main pillars of all branches of faith. this is the reason why the cultivation of the six pillars of faith must be truly one with the heart and ingrained. Furthermore, if we pay attention to the many verses and hadiths of the prophet, we will find that two pillars of faith are often mentioned together. they are; faith in God and faith in the last day. We can conclude that the tens of branches of faith are the main pillars of faith, which are six pillars of faith, and the six main pillars of faith, which are the two pillars, namely faith in God and the Last Day. Allah knows best. 


\section{Al-Qur'an}

Al-Qur'an is nothing but the only curriculum that Allah Subhanahu wa Ta'ala gave to His messengers. Prophet Muhammad SAW did not get any other guidance except the Al-Qur'an and the guidance of revelation from him which we often call hadith. Therefore the Al-Qur'an is always the benchmark. A generation will be superior when the qur'an lives in that generation and when the qur'an is far away from generations, the generations and people of the earth will fall back into the darkness of ignorant life and Muslims are unable to become leaders without al qur'an.

Umar bin Khattab says that Rasulullah SAW said:

"Verily, Allah raised communities with this (Al-Qur'an) and with it also destroyed others."

Allah Subhanahu wa Ta'ala created humans with the task of prospering the earth and Al-Qur'an is the perfect guide from the Creator. Al-Qur'an is the word of Allah who guides us in this world to live in His heaven. Al-Quran contains the knowledge of the world and the hereafter. A comprehensive encyclopedia in which many world sciences have not been revealed from the Al-Qur'an. These are the complete instructions for the prosperity of this earth. 3. Prophet

The thing that is related to prophetic and becomes the basis of this prophetic paradigm is the view of a noble human figure called a prophet. The prophetic paradigm is as follows:

1) Prophets are humans who were created by Allah SWT and given the task of giving knowledge from Allah so that with that knowledge humans can be safe and happy in the world and the hereafter.

2) The prophets are people whom Allah has given the ability to be able to relate and communicate with Him as well as with His creatures who are not only humans.

3) Among the prophets there were some that Allah gave him books. They compile the messages of Allah and preach them to humans.

4) There are some prophets sent by Allah only for certain people. However, some were sent to the world and all mankind, he is the Prophet Muhammad SAW. With the knowledge obtained from the preaching and teachings of the prophets, humans can be devout and can manage the world that God has left to them as khalifa. Thus, prophets and humans can realize their service in the world as servants of Allah and khalifa.

4. Science

Knowledge is profound knowledge according to Arabic terminology. Knowledge is taken from the word عِ w w w w which also means knowledge of the essence of something.

There are many ways to get this knowledge, such as through the process of learning, researching, searching, and taking. There is also the knowledge that is gained without going through these processes. This is called revelation or inspiration that Allah has given, both sensory and non-sensory empirical (Khoiron, 2004). However, the knowledge that humans acquire after going 
through various processes cannot be fully confirmed to be able to completely solve all kinds of problems of natural phenomena in macro as well as problems of human life. Many things cannot be reached by reason or science because the knowledge obtained by humans is limited. Therefore, it is fitting for humans to realize the limitations of their mind and knowledge and rely on their soul and body to the transcendental God Almighty. To reach knowledge, humans are indeed given knowledge by Allah SWT. This is contained in surah Al Baqarah verse 31: "He (Allah) taught Adam the names of all things; then He presented the things to the angels and said: "Tell Me the names of those if what you say is true?" (Allah did this to show Adam's special qualities of learning and memory). (RI, 2008)

Humans get knowledge because of the abilities and teachings that God has given. From this information, it can be concluded that knowledge comes from Allah and He gives humans the ability to be able to identify all things in the form of objects of knowledge with their senses and intuition.

\section{METHODS}

This research was conducted at SMP Bina Insan Boarding School in Ciawi sub-district, Bogor district. This study uses 2 types of research. The first is field research, namely research in which data collection is carried out in the field, and the second is library research. (Arif, 2008) states that a research library is a study whose data is sourced and obtained from related literature and literature studies, then it is analyzed theoretically and philosophically, then it is concluded and discussed its relevance and context.

This research uses a philosophical, phenomenological, and pedagogical approach. (1) A philosophical approach is formulating clear, systematic, and comprehensive conceptions of prophetic education in the realm of epistemology. (2) A phenomenological approach to developing thoughts or ideas about prophetic education in schools or educational institutions in a logical, critical and systematic manner to produce a new paradigm in the implementation of prophetic education. (3) A pedagogical approach is to express and interpret various prophetic education concepts so that they can be understood easily.

This research is descriptive-analytic research, which attempts to describe the ideas or methods of prophetic education according to the way of the Rasulullah. However, indirect research on the implementation of prophetic education at the junior high school level uses a descriptive qualitative approach. Nasution stated that the descriptive qualitative approach was essentially observing people in their environment, interacting with them, trying to understand their language and their interpretation of the world and its surroundings. (Nasution, 2003). 


\section{RESULTS AND DISCUSSION}

Planning for Prophetic Education at SMP Bina Insan Boarding School Ciawi Bogor

Based on observations, interviews, and the entire research process, the authors conclude that in planning for prophetic education at Bina Insan Boarding School for Junior High School level, the foundation first thinks about its objectives and activities. Then the foundation communicates the results to the principal. Student activities are usually based on a certain method, plan, or logic, not carelessly.

The prophetic education planning contained in the learning activities at Bina Insan Boarding School for Junior High School level has been inspired by what was said by the Prophet's friend, Jundub bin Abdillah, about the stages of friends in studying with the Prophet. He said that the friends studied faith first before learning the Alquran. So when the friends studied the Alquran their faith increased. Then the atsar (the words of a Sahaba) were outlined in the book mukhtashar syu'bul iman written by Sheikh Imam Ahmad Al Baihaqi. This concept is integrated into every subject at SMP Bina Insan Boarding School Ciawi. The prophetic values that are implanted can be developed in learning activities. That is, the teacher implements the overall prophetic values according to the guidelines.

Planning for prophetic education at SMP Bina Insan Boarding School Ciawi in the process runs according to the provisions set by the government, as contained in the 2013 curriculum, then developed into a syllabus and poured into the lesson plan (RPP) and books (teacher work program) for one semester. Furthermore, it is given deepening and integrated with prophetic education. The principal determines the prophetic concept, then provides direction and briefing to teachers related to prophetic education. As stated by the principal of SMP Bina Insan Boarding School Ciawi in an interview that:

Prophetic education planning begins with the 2013 curriculum which has been integrated with the values of faith, Quran, manners, and morals into the syllabus and lesson plan (RPP), then the implementation is translated into learning.

Planning for prophetic education at SMP Bina Insan Boarding School Ciawi is generally carried out in several stages: determining the types of prophetic education activities, determining the goals of prophetic education, and preparing steps for the implementation of prophetic education. The school's efforts to internalize prophetic values outside of learning activities through Quran cycle activities, extracurricular activities, religious activities, arts, sports, and other activities that can support the application of prophetic education, are then explored and applied further.

The prophetic values included in the planning are as follows : 


\begin{tabular}{|c|c|c|}
\hline No & eligion (Islamic Education) & Prophetic values \\
\hline 1 & Behave by religious syari'at & $\begin{array}{l}\text { Integrity, istiqomah, practice the } \\
\text { example of the prophet }\end{array}$ \\
\hline 2 & $\begin{array}{l}\text { Respect the diversity of religions, } \\
\text { nations, ethnicities, races, socio- } \\
\text { economic groups, and cultures in the } \\
\text { global order }\end{array}$ & $\begin{array}{l}\text { Respect for others. The role of } \\
\text { Tasamuh (tolerance) of the } \\
\text { Messenger of Allah, the practice } \\
\text { of the story of the Khlifa Umar, } \\
\text { etc. }\end{array}$ \\
\hline 3 & $\begin{array}{l}\text { Unde } \\
\text { onese }\end{array}$ & $\begin{array}{l}\text { Be aware of laws and regulations, } \\
\text { study hard, care for the } \\
\text { environment and nature }\end{array}$ \\
\hline 4 & $\begin{array}{l}\text { rences of opi } \\
\text { others }\end{array}$ & $\begin{array}{l}\text { The attitude of caring and } \\
\text { concern for others }\end{array}$ \\
\hline 5 & $\begin{array}{l}\text { Maintain cleanliness, health, endurance, } \\
\text { and physical fitness in life following } \\
\text { religious guidance }\end{array}$ & $\begin{array}{l}\text { imitate the healthy lifestyle of } \\
\text { Rasulullah (Peace be upon him) }\end{array}$ \\
\hline
\end{tabular}

Organizing Professional Education at SMP Bina Insan Boarding School Ciawi Bogor

The process of organizing prophetic education at SMP Bina Insan Boarding School considers and empowers potential human resources, types of activities, schedule of activities and available funding sources. The organization of human resources in prophetic education at SMP Bina Insan Boarding School Ciawi is described as follows:

1) The coordinator of the implementation of prophetic education is the vice principal of the boarding school in the field of pesantren SMP Bina Insan Boarding School.

2) Supervising teachers are religious teachers and Al-Qur'an teachers who are in charge of guiding, supervising, evaluating, and assessing the extent of the implementation of prophetic education in SMP Bina Insan Boarding School.

Based on the results of interviews with the deputy principal of the pesantren field as the head of the coordinator, the details of the positions and their respective functions are in the following table:

\begin{tabular}{|c|c|l|}
\hline No & Position & \multicolumn{1}{c|}{ Job Description } \\
\hline 1 & $\begin{array}{c}\text { Deputy head of } \\
\text { the pesantren }\end{array}$ & $\begin{array}{l}\text { Coordinates with teachers in the preparation of } \\
\text { teaching preparation/lesson plans, and other } \\
\text { teacher administration }\end{array}$ \\
\hline 2 & $\begin{array}{l}\text { Religion } \\
\text { Teacher }\end{array}$ & $\begin{array}{l}\text { Pay attention to, supervise, and evaluate student } \\
\text { behavior both inside the classroom and outside the } \\
\text { classroom }\end{array}$ \\
\hline 3 & $\begin{array}{c}\text { Qur'an } \\
\text { teachers }\end{array}$ & $\begin{array}{l}\text { Coordinate with religious teachers in determining } \\
\text { the text and context of the verses of the Qur'an }\end{array}$ \\
\hline
\end{tabular}




\begin{tabular}{|l|l|}
\hline & $\begin{array}{l}\text { related to the subject matter and assessing student } \\
\text { behavior both inside and outside the classroom }\end{array}$ \\
\hline
\end{tabular}

Apart from organizing human resources, SMP Bina Insan Boarding School also organizes prophetic education implementation facilities. Details of the implementation facilities include:

1) Prophetic education guidebook, namely the handbook of all students and mentor teachers.

2) Book for determining CPP (Positive Behavior Notes) and CPN (Negative Behavior Notes).

3) Prophetic education modules and textbooks on prophetic education to be taught inside and outside the classroom.

4) Data board.

The Implementation of Prophetic Education at SMP Bina Insan Boarding School Ciawi Bogor

Based on the results of observations and interviews, the implementation of prophetic education in learning activities at Bina Insan Boarding School Junior High School is carried out by instilling prophetic values in educators and students including teaching-learning methods and attitudes. All follow the example of the Prophet as a model for noble morals. The prophetic values implanted in the activity are as follows.

\begin{tabular}{|c|l|}
\hline Prophetic Value & \multicolumn{1}{c|}{ Character and Behavior } \\
\hline Faith Value & $\begin{array}{l}\text { Diligently worship, believe in, and practice the } \\
\text { pillars of Islam }\end{array}$ \\
\hline Adab/Courtesy & $\begin{array}{l}\text { Honest, polite, culture of queuing, not cheating, } \\
\text { throwing garbage in its place, discipline, attendance } \\
\text { at class, on time, gentle in speaking, respect and } \\
\text { respect for others, care for others and the } \\
\text { environment, responsibility. }\end{array}$ \\
\hline Akhlak/Morals & $\begin{array}{l}\text { Stay away from alcohol, brawl, adultery, drugs, porn } \\
\text { action, and pornography. }\end{array}$ \\
\hline
\end{tabular}

The implementation of prophetic values is also carried out outside of teaching and learning activities in the classroom. This implementation is divided into two activities, namely routine activities, and non-routine activities as well as in aspects outside of activities.

1) Routine Activities

Routine activities carried out at SMP Bina Insan Boarding School Ciawi include: the culture of Salim and greetings, MABIT (night of faith and piety) every Sunday night, the cycle of the Qur'an for two weeks every 3 months, flag ceremony every Monday, work daily devotions, motivational seminars, religious activities such as dhuha prayer, qiyamul lail, Monday-Thursday 
fasting, Ramadhan Islamic boarding schools, Muhadloroh and great studies. With routine activities, students are expected to have prophetic values such as religious (diligence and enthusiasm for worship), love of the Qur'an, the spirit of the congregation, being competitive in kindness, and caring for the environment.

SMP Bina Insan has a student organization that is involved in carrying out flag ceremonies every Monday morning, waking and leading students when they want to pray Fajr, helping to control conditions for worship activities such as prayer and recitation, boarding activities such as room pickets and routine community service, holding competitions between class, helps condition the activities or events determined by the school as well as holding holiday activities. By participating in activities and participating in OSIS management, students can hone and train soft skills and responsibility in organizations.

One of the routine activities at Bina Insan Boarding School Middle School is extracurricular activities. Extracurricular activities at Bina Insan Boarding School Ciawi Middle School in sports are futsal, badminton, swimming, archery, and self-defense. Meanwhile, in the arts, they are nasyid and, vocal group. As for the religious sector, there are Quranic clubs, Muhadloroh, Arabic club, and English club. And other fields such as cooking class, scouting, and PMR. In extracurricular activities, students not only participate in activities but are also provided with religious understanding related to extracurricular activities that are followed. As in archery extracurricular activities, religious understanding is given about the benefits of sport from a religious perspective, the benefits of archery, and its history. This is expected so that students do not just do physical activities but also increase their Islamic spirit and insight. The basis of this activity is the hadith of the prophet that strong Muslims are more liked and loved than weak Muslims.

\section{2) Non-Routine Activities or Spontaneous Events}

Spontaneous activities are activities that are carried out spontaneously at that time. This activity is usually carried out when the teacher or principal is aware of inappropriate behavior and attitudes. At that time the teacher also corrects or reprimands or gives CPN (negative behavior notes) to students so that students get lessons and will not re-perform these negative actions or behaviors. The forms of spontaneous activities at Bina Insan Boarding School Middle School that require spontaneous actions are also such as 3 culture (senyum/smile, salam/say salam, greetings/sapa), throwing trash in its place, screaming that disturbs others, dressing not according to school regulations, behaving inappropriately, sleeping or rowdy in class, mix with the opposite sex (ikhtilath) and so on. This was proven when one of the teachers reprimanded students for being disorderly in their clothes and then ordered them to tidy up. With spontaneous activities and actions, students are expected to have the values of manners which are part of prophetic education. Adab values such as discipline, love of beauty, care for the environment, and responsibility. 


\section{3) Other Aspects}

For the condition and situation of the school to be more supportive in the implementation of prophetic education, conditioning is needed. The forms of conditioning at SMP Bina Insan Boarding School Ciawi are toilets that are clean and always cleaned, a beautiful environment, trash cans that are available in various places, learning tools are placed regularly, the class separation between students (boys) and students (girls), gazebo as a means of memorizing the Qur'an, hygienic kitchens and canteens, mosques and prayer rooms as well as competent human resources in the field of religion and the Qur'an. This reflects school life that instills ethical values in the form of caring for the environment.

Apart from the above, the role models of educators and education personnel are also part of the implementation of prophetic education at SMP Bina Insan Boarding School. This is shown by teachers and all school members who make every effort to emulate the Prophet Muhammad, practice his sunnah, and follow every culture and rules that have been determined by the school. The exemplary forms carried out by teachers and school members are not smoking, dress modestly and neatly, discipline in work, honesty, diligent worship, regular congregational prayers, attention to students, speaking polite words, having good personality actively and passively in activities - routine school activities.

Evaluation of the Implementation of Prophetic Education at SMP Bina Insan Boarding School Ciawi Bogor

Based on the results of interviews and document studies, evaluation of prophetic education at Bina Insan Boarding School Junior High School is carried out using an assessment format or evaluation sheet notes, observing the behavior and attitudes of students. There are three assessment techniques in competency assessment, namely written techniques, practical techniques, group, and independent assignments. The teacher also assesses the behavior of students in learning activities by using evaluation guidelines for cognitive and affective aspects that refer to prophetic values. Each teacher has a student guidance note sheet to assess the morals and manners of students at each competency standard they teach. Each month, the coordinator recapitulates the students' positive behavior records and negative behavior notes to see the achievement of the prophetic education goals that are implemented. Based on the description above, it can be concluded that the evaluation of prophetic education at SMP Bina Insan Boarding School Ciawi has been running and implemented by the school.

\section{CONCLUSION}

Based on the results of research and discussion regarding the implementation of prophetic education at Bina Insan Boarding School for the Junior High School level, the following conclusions are obtained. 
1) Planning for prophetic education at SMP Bina Insan Boarding School is carried out by the foundation and the principal. Prophetic education is planned to be carried out through learning activities and activities outside of learning. Prophetic education through learning activities utilizing teachers developing prophetic values that are broken down into students' faith, manners, and morals and then developed in learning tools such as syllabus, and lesson plans. Meanwhile, prophetic education through activities outside of learning is utilizing teachers developing programs for instilling the values of faith, manners, and morals through self-development activities, school culture, and extracurricular activities.

2) The organization that is implemented to implement prophetic education at Bina Insan Boarding School takes into account the following factors: (a) activity coordinator and supervisor, (b) owned facilities, (c) owned infrastructure, and (d) resources costs and cost allocation.

3) Implementation of prophetic education in integrated learning activities in each subject. Teachers enter prophetic values in each subject. The prophetic values implanted in activities are adjusted to the values of faith, manners, and morals. Meanwhile, outside of learning activities, prophetic education is packaged in the form of self-development activities, namely: routine activities, spontaneous activities, and other aspects that include modeling and conditioning.

4) Evaluation of education at Bina Insan Boarding School Junior High School is carried out using an assessment format or evaluation sheet notes, observing the behavior and attitudes of students. There are three assessment techniques in competency assessment, namely written techniques, practical techniques, group, and independent assignments. Evaluation of prophetic education outside of learning activities is carried out by observing student behavior, violation checklist, CPP (Positive Behavior Note) and CPN (Negative Behavior Note) scoring or accumulating points, all of which are contained in the discipline book for students of SMP Bina Insan Boarding School Ciawi.

\section{REFERENCES}

Al-Ik, K. bin A. (2017). Prophetic parenting. Pro-U Media. www.divapressonline.com

Arif, M. (2008). Pendidikan Islam Transformatif. LKiS Pelangi Aksara.

Asmani, J. M. (2013). Kiat Melahirkan Madrasah Unggulan: Merintis dan Mengelola Madrasah yang Kompetitif. Diva Press.

Fitri Zainul, A. (2014). Pendidikan Karakter Berbasis Nilai dan Etika. Ar Ruzz Media.

Khoiron, R. (2004). Pendidikan Profetik. Pustaka Pelajar. 
Nasution. (2003). Metodologi Penelitian Naturalistik Kualitatif. Tarsito PT.

Remaja Rosda Karya.

RI, D. A. (2008). Al-hikmah Al-Qur'an dan Terjemahannya. CV Penerbit J-ART.

Roqib, M., \& Abdul Wachid, B. S. (2011). Prophetic education: kontekstualisasi filsafat dan budaya profetik dalam pendidikan. STAIN Press.

Shofan, M. (2004). Pendidikan Berparadigma Profetik. IRCiSoD. 